\title{
LACK OF ASSOCIATION BETWEEN GENOTYPES AND VIRULENCE FACTORS IN C. ALBICANS STRAINS ISOLATED FROM VAGINAL SECRETION
}

\author{
Cristiane Suemi Shinobu ${ }^{1}$; Sueli Fumie Yamada Ogatta ${ }^{2}$; Fenando Bizerra² Luciana Furlaneto $^{2}$; \\ Rosane Marina Peralta ${ }^{3}$; Terezinha Inez Estivalet Svidzinski ${ }^{1}$; Marcia Edilaine Lopes Consolaro ${ }^{1 *}$
}

\begin{abstract}
'Departamento de Análises Clínicas, Universidade Estadual de Maringá, Maringá, PR, Brasil; ${ }^{2}$ Departamento de Microbiologia, Universidade Estadual de Londrina, Londrina, PR, Brasil; ${ }^{3}$ Departamento de Bioquímica, Universidade Estadual de Maringá, Maringá, PR, Brasil.
\end{abstract}

Submitted: March 06, 2007; Approved: July 16, 2007.

\begin{abstract}
The physiopathogenesis of vulvovaginal candidiasis (VVC) is still not completely elucidated. The objective of this study was to evaluate if there is a relationship between the different genotypes of Candida albicans, their main agent and the virulence of this yeast in vaginal isolates, and to check if there are laboratorial markers that can predict the ability of each isolate to develop VVC independently of symptoms. The production of exoenzymes protease, phospholipase and haemolysin, resistance to hydrogen peroxide, and the genotype were determined. Genotype A was predominant (75\%), protease, phospholipase and haemolytic activity were highly expressed, and the majority of the yeasts were sensitive to $\mathrm{H}_{2} \mathrm{O}_{2}$ in 1 and 2 hours of exposure, suggesting that these factors are important in the virulence of vaginal isolates. However they did not have any correlation with the genotypes. The different isolates expressed similar virulence potential, suggesting that other factors relating to the yeasts and the host must participate in the development of the clinical disease.
\end{abstract}

Key words: C. albicans, vulvovaginal candidiasis, genotype, virulence factors

\section{INTRODUCTION}

Candida albicans is the most important species of yeast in the female genital tract. About 20 to $25 \%$ of healthy and completely asymptomatic women present positive vaginal secretion cultures for this fungus. Around $75 \%$ of adult women have at least one episode of vulvovaginal candidiasis (VVC) during their life, with prevalence of C. albicans in 70-90\% (4). Some of these patients will experience episodes again and 5\% will suffer recurrent VVC (RVVC) (13).

According to Ziarrusta (23), VVC is caused by the transformation of the yeasts from coloniser status (asymptomatic) to infectious agents (symptomatic vaginitis). However, the factors responsible for this transformation and the mechanisms that result in the pathological effects of $C$. albicans are poorly understood (7).
C. albicans presents various virulence factors such as exoenzyme secretion, capacity of adherence and morphogenesis (2). The association of clinical symptoms with the production of germ tubes by the yeast has recently been demonstrated (5). The production of exoenzymes such as proteases and phospholipases are factors which have been classically understood $(6,8)$. Others, such as haemolytic activity $(11,12)$ and the resistance to hydrogen peroxide $(18,19)$, are still little studied, especially in vaginal isolates.

Recent advances in technologies based in molecular biology have enabled the increase of information about the genetic diversity of $C$. albicans. The genotypes of this yeast have been associated with different infection sites (18) and with susceptibility to antifungal drugs (20). Recently, Chong et al. (4), in a study of genetic similarities by random amplification of the polymorphic DNA (RAPD) of Malaysian patients with VVC

*Corresponding Author. Mailing address: Departamento de Análises Clínicas, Universidade Estadual de Maringá (UEM), Maringá, Paraná, Brasil. Av. Colombo, 5790, CEP: 87020-900, Brasil. Tel.: +55 44 3261-4795; Fax: +55 44 3263-1387. E-mail: melconsolaro@yahoo.com.br 
and RVVC, found that patients with RVVC are more frequently colonised by the same isolate of Candida. However, little is known about the relation of the genotypes with the virulence capacity of $C$. albicans in the vagina. The genotyping is based in the gene rRNA of this fungus. The group I intron is a 379base-long sequence insert at position 2,420 of the rRNA gene of some C. albicans strains (genotype B), or do not have this intron (genotype A) and a mixture of intron-containing and intronless 26S rRNA genes (genotype C). Of the pathogenic yeasts, only $C$. albicans and $C$. dubliniensis possess the $26 \mathrm{~S}$ rRNA intron (20).

In spite of the technological advances, the physiopathogenesis and the clinical management of VVC remain unclear. Considering the limitation of the diagnosis of VVC only by clinical evaluation (16), the purpose of this study was to evaluate if there are laboratorial markers that can predict the capacity of a determined $C$. albicans isolate to develop VVC and also if there is a relation between genotypes and virulence for this fungus in vaginal isolates.

\section{MATERIALS AND METHODS}

\section{Sampling, culturing procedures and identification of yeasts}

Research has been undertaken with $C$. albicans isolates of the vaginal secretions the women at the Teaching and Research in Clinical Analyses Laboratory (LEPAC) of the State University of Maringá, PR Brazil. They were identified as C. albicans initially using cervical-vaginal material collected for fungus culture and samples were seeded in plates with Sabouraud Dextrose Agar (SDA- Difco, USA), plus chloramphenicol (Sigma, USA) $0.2 \mathrm{~g} / \mathrm{l}$, incubated at $35^{\circ} \mathrm{C}$, for $48-72$ hours. A pool of growing colonies were subcultivated in CHROMagar Candida $^{\circledR}$ (Probac, França) to investigate purity of culture and colony's color. The yeasts growing this differential selective medium were identified, according to classical methodology $(9,10)$.

\section{Identified molecular and genotyping}

The isolates were molecularly identified as $C$. albicans using the methodology of Ahmad et al. (1) and genotyped using rDNA sequence analysis. Their genotype was determined by PCR using primers that span the intron site in the 26S rRNA gene: CaLSU-F (5'-GTTAATCCATTCATGCGCGTCAC-3') and CaLSU-R (5'-GTTTCCTGCCCAGTGCTCTG-3'). PCR was performed according Sugita et al. (2002).

\section{Production of phospholipases and proteinases}

The production of phospholipases was determined using the egg-yoke plate method described by Price et al. (15) and the extracellular proteinase activity by the bovine serum albumin plate method described by Ruchel et al. (17), both with incubation for $96 \mathrm{~h}$ at $37^{\circ} \mathrm{C}$. The presence of enzymes was detected by the formation of a clear zone of hydrolysis around the colony. The enzymatic activity $(\mathrm{Pz})$ was measured by ratio between the diameter of the colony and the diameter of the colony plus the zone of precipitation. The tests were conducted in duplicate on 3 different occasions. The isolate $C$. albicans $12 \mathrm{~A}$, donated by the Institute of Biomedical Sciences University of São Paulo, was used as a positive control.

\section{Hemolytic activity}

The hemolytic activity was determinated by plate assay method described by Luo et al. (11). Spots have been made on a sugar-enriched sheep blood agar medium. The latter medium was prepared by adding $7 \mathrm{ml}$ of fresh blood (CPPI-Brazil) to 100 $\mathrm{ml}$ of SDA supplemented with $3 \%$ glucose (Sigma, USA) providing a final concentration of $7 \%$. The final $\mathrm{pH}$ of the medium so prepared was $5.6 \pm 0.2$. The plates were incubated at $37^{\circ} \mathrm{C}$ in $5 \% \mathrm{CO}_{2}$ for $48 \mathrm{~h}$. The presence of a distinct translucent halo around the inoculum site, viewed with transmitted light, indicated positive hemolytic activity. The diameters of the zones of lysis and the colony were measured, and this ratio (equal to or larger than 1) was used as a hemolytic index to represent the intensity of the hemolysin production by $C$. albicans. The assay was conducted in duplicate on three separate occasions.

\section{Susceptibility to hydrogen peroxide}

Susceptibility to hydrogen peroxide was investigated according Vilela et al. (22). The yeast were cultured in a 96-well microplate beginning with an inocultion of $2 \times 10^{6} \mathrm{ml}^{-1}$ in RPMI 1640 (Sigma, Germany) supplemented with 1 or $10 \mathrm{mM}$ hydrogen peroxide (Sigma, USA). They were incubated at $37^{\circ} \mathrm{C}$ for $1-2 \mathrm{~h}$ and spread in plates with SDA for the determination of viability by counting the colony formation units (cfu).The assay was conducted in quadruplicate on two separate occasions.

\section{RESULTS}

\section{Strains}

One hundred and sixty-one patients were evaluated. Positive fungus culture had a frequency of $21.7 \%$ (35 patients). Twenty C. albicans was isolate and utilized in this study (numbered from 1 to 20 by isolation order).

\section{Genotype distribution}

The genotype distribution of the 20 C. albicans was: A $75.0 \%(\mathrm{n}=15), \mathrm{B}$ and $\mathrm{C} 10.0 \%$ each $(\mathrm{n}=2)$. One isolate (number 10) was not molecularly identified as $C$. albicans and for this reason was excluded from the study of virulence factors. The PCR products obtained are shown in Fig. 1.

\section{Relation between the genotypes and the virulence factors}

The relation between the genotypes and the expression of virulence factors of the 19 samples of $C$. albicans are shown in Table 1. 


\section{Production of phospholipases and proteinases}

All of the isolates showed phospholipase and protease activity, however in $2(10.5 \%)$ the phospholipasic activity was high and $17(89.5 \%)$ exhibited intermediate activity. In relation to the proteases, 7 isolates (36.8\%) showed high activity and 12 $(63.2 \%)$ intermediate activity.

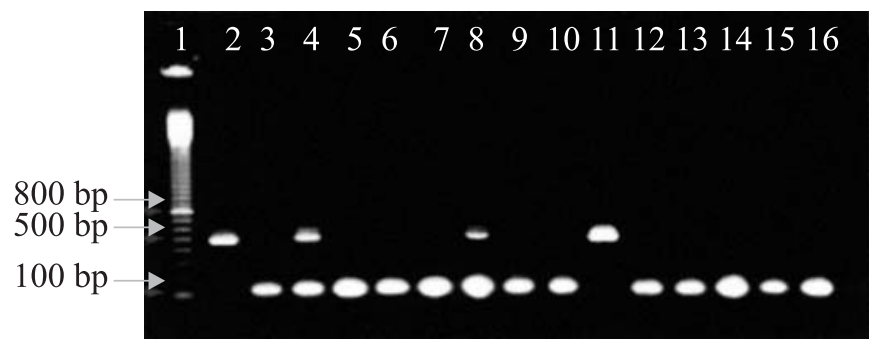

Figure 1. PCR amplification of DNAs from C. albicans using primers CaLSU-F and CaLSU-R. Lane 1, 100-bp molecular size marker. Lanes genotype A (133-bp product), lane genotype B (512-bp product), lane genotype $\mathrm{C}$ (133- and 512-bp products). After electrophoresis, the $1.2 \%$ agarose gel were stained with ethidium bromide $\left(1 \mu \mathrm{g} / \mathrm{ml}^{-1}\right)$, visualized and archived on Image Master VDS 1044- 14 (Pharmacia Biotech).

\section{Haemolytic activity}

All of the isolates showed haemolytic activity, but quantitative differences were observed. Two samples (1 and 8 ) produced partial haemolysis whereas all the others produced total haemolysis.

\section{Susceptibility to hydrogen peroxide}

Isolates 1 and 2 demonstrated a high capacity of survival in $\mathrm{H}_{2} \mathrm{O}_{2}(1 \mathrm{mM})$ until $2 \mathrm{~h}$ of exposure. The others showed variable resistance, however after $2 \mathrm{~h}$, the percentage of recovery was uniformly low or absent. All the isolates were sensitive to $\mathrm{H}_{2} \mathrm{O}_{2}$ $(10 \mathrm{mM})$ exposition, independent of the time of exposure.

\section{DISCUSSION}

It was not possible to establish a relationship between the genotypes and the virulence factors. The combination of these parameters did not seem to be useful for predicting if a certain genotype is causing, or has a higher chance of causing, clinical infection. Vidotto et al. (21), in a study with $C$. albicans from various sites, also did not find a relationship between phospholipasic activity and genotypes. On the other hand, for Sugita et al. (20), in blood samples, phospholipase and proteinase secretion was higher in genotype B. In this work genotype A was predominant, differing from Vidotto et al. (21), who found equivalence between genotypes A and B in vaginal isolates.

Table 1. The relation between the genotypes and virulence factors of vaginal secretion C. albicans isolates.

\begin{tabular}{|c|c|c|c|c|c|c|}
\hline \multirow{2}{*}{ Strains } & \multirow{2}{*}{ Genotypes } & \multirow{2}{*}{$\begin{array}{l}\text { Phospholipase } \\
\text { activity }\end{array}$} & \multirow{2}{*}{$\begin{array}{l}\text { Protease } \\
\text { activity }\end{array}$} & \multirow{2}{*}{$\begin{array}{l}\text { Haemolytic } \\
\text { activity }\end{array}$} & \multicolumn{2}{|c|}{$\mathrm{H}_{2} \mathrm{O}_{2} 1 \mathrm{mM}$} \\
\hline & & & & & \multicolumn{2}{|c|}{ (survival \%) } \\
\hline 1 & B & Intermediate & Intermediate & 2.0 & 79.2 & 42.2 \\
\hline 2 & A & Intermediate & Intermediate & 2.0 & 68.2 & 32.8 \\
\hline 3 & $\mathrm{C}$ & Intermediate & High & 2.1 & 54.2 & 4.0 \\
\hline 4 & A & Intermediate & High & 1.4 & 40.0 & 1.7 \\
\hline 5 & A & Intermediate & Intermediate & 2.0 & 41.8 & 2.5 \\
\hline 6 & A & Intermediate & Intermediate & 2.2 & 45.6 & 0.4 \\
\hline 7 & A & Intermediate & High & 1.9 & 55.7 & 0.4 \\
\hline 8 & A & High & High & 2.2 & 40.4 & 1.4 \\
\hline 9 & A & Intermediate & High & 1.9 & 18.2 & 2.4 \\
\hline 11 & $\mathrm{C}$ & Intermediate & Intermediate & 1.9 & 64.4 & 2.1 \\
\hline 12 & A & Intermediate & Intermediate & 2.2 & 39.6 & 0.9 \\
\hline 13 & $\mathrm{~A}$ & Intermediate & Intermediate & 2.2 & 82.4 & 0.8 \\
\hline 14 & A & Intermediate & Intermediate & 2.2 & 64.8 & 0.0 \\
\hline 15 & $\mathrm{~A}$ & Intermediate & Intermediate & 2.0 & 55.3 & 2.7 \\
\hline 16 & $\mathrm{~B}$ & Intermediate & High & 2.0 & 36.5 & 1.5 \\
\hline 17 & A & Intermediate & Intermediate & 2.2 & 22.4 & 4.3 \\
\hline 18 & A & Intermediate & Intermediate & 1.9 & 36.1 & 6.3 \\
\hline 19 & A & Intermediate & Intermediate & 2.2 & 87.8 & 10.1 \\
\hline 20 & A & High & High & 1.9 & 24.5 & 0.9 \\
\hline
\end{tabular}


In this study, the haemolytic, phospholipase and protease activity were positive and had highly expressed elevations, which confirms the idea that the virulence of $C$. albicans results from the combination of multiple factors (3). These three factors seem to be very important in the virulence of vaginal isolates. The samples numbered 8 and 20, both genotype A, had coordinately high phospholipase and protease secretions, leading to the belief that they must be the most virulent.

Haemolytic activity is associated with the ability of pathogenic organisms to acquire iron from mammalian cells, a critical stage in the establishment of an infection (14). However, the relationship between the production of haemolysin and virulence needs to be better evaluated. In the samples studied in this research, the production of haemolysin was always present and, to a large degree, reinforces the idea that the virulence potential is independent of the genotype.

The production of $\mathrm{H}_{2} \mathrm{O}_{2}$ and the maintenance of the $\mathrm{pH}$ for the species of Lactobacillus are important to reduce the overgrowth of microorganisms in bacterial vaginosis. Surprisingly, there is no information about whether this mechanism also influences the development of VVC. In this study, the susceptibility to $\mathrm{H}_{2} \mathrm{O}_{2}$ was not itself related to the genotypes or to the other virulence factors studied. However, the results suggest that the growth of the majority of $C$. albicans will be controlled by the presence of Lactobacillus, resulting in the situation of equilibrium or colonisation. This could be possible as the species of Lactobacillus that produces $\mathrm{H}_{2} \mathrm{O}_{2}$ are present in the vagina of $98 \%$ of normal women (18). In spite of this evidence, cases of VVC with normal lactobacilar_flora have been observed. Therefore, other studies relating to the virulence factors studied here should be conducted with in vivo tests, as the factors related to the host are also important in the establishment of the infection.

In conclusion, we have demonstrated that classical factors, like protease and phospholipase activity, as much as the most recent, such as haemolytic activity and susceptibility to $\mathrm{H}_{2} \mathrm{O}_{2}$, do not have predominance in a specific genotype in relation to the virulence factors studied in vaginal secretion isolates of $C$. albicans. However, protease, phospholipase and haemolytic activity were highly expressed, suggesting that these virulence factors are important in vaginal isolates. Generally, the different isolates expressed similar virulence potential, reinforcing the necessity for new studies and also that other factors related to the yeasts and the host, such as adherence capacity, must be involved in the development of the disease.

\section{ACKNOWLEDGEMENTS}

The authors wish to thank Peter Grimshaw for revision this article. This work was supported by Conselho Nacional de Desenvolvimento Científico e Tecnológico (CNPq) (n 474542/ 2003-3).

\section{RESUMO}

\section{Ausência de associação entre genótipos e fatores de virulência em $C$. albicans isoladas de secreção vaginal}

A fisiopatogenia da candidíase vulvovaginal (CVV) não está completamente elucidada até o presente momento. O objetivo deste estudo foi avaliar se exite relação entre os diferentes genótipos de Candida albicans, seu principal agente, e a virulência desta levedura em isolados vaginais, e checar se existem marcadores laboratoriais que possam predizer a habilidade de cada isolado para desenvolver CVV independentemente dos sintomas. Foram determinados a produção de exoenzimas protease, fosfolipase and hemolisina, resistência ao peróxido de hidrogêncio, e genótipo. O genótipo A foi predominante $(75 \%)$, protease, fosfolipase e atividade hemolítica foram alevadamente expressos, e a maioria das leveduras foram sensíveis ao $\mathrm{H}_{2} \mathrm{O}_{2}$ em 1 e 2 horas de exposição, sugerindo que estes fatores são importantes na virulênciae de isolados vaginais. Entretanto, não houve nenhuma correlação com os genótipos. Os diferentes isolados expressaram potencial de virulência similares, sugerindo que outros fatores relacionados às leveduras e ao hospedeiro devem participar no desenvolvimento da doença clínica.

Palavras-chave: C. albicans, candidíase vulvovaginal, genótipo,fatores de virulência

\section{REFERENCES}

1. Ahmad, S.; Khan, Z.; Mustafa, A.S.; and Khah, Z.U. (2002). Seminested PCR for diagnosis of candidemia: comparison with cultura, antigen detection, and biochemical methods or species identification. J. Clin. Microbiol., 40, 2483-2489.

2. Calderone, R.; Fonzi, W.A. (2001). Virulence factors of Candida albicans. TRENDS Microbiol., 9, 327-335.

3. Candido, R.C.; Azevedo, R.V.P.; Kemesu, M.C. (2000). Enzimotipagem de espécies do gênero Candida isoladas de cavidade bucal. Rev. Soc. Bras. Medic. Trop., 33, 437-442.

4. Chong, P.P.; Lee, Y.L.; Ian, B.C.; Ng, K.P. (2003). Genetic relatedness of Candida strais isolated from women with vaginal candidiasis in Malaysia. J. Med. Microbiol., 52, 657-666.

5. Consolaro, M.E.L.; Abertoni, T.A.; Svidzinski, A.E.; Peralta, R.M.; Svidzinski, T.I.E. (2005). Vulvovaginal candidiasis is associated with the production of germ tubes by Candida albicans. Mycopathol., 159, 501-507.

6. De Bernardis, F.; Sullivan, P.A.; Cassone, A. (2001). Aspartyl proteinases of Candida albicans and their role in pathogenicity. Med. Mycol., 39, 303-313.

7. Fidel Jr, P.L.; Barousse, M.; Espinosa, T.; Ficarra, M.; Sturtevant, J., Martin, D.H.; Quayle, A.J., and Dunlap, K. (2004). An intravaginal live Candida challenge in humans leads to new hypotheses for the immunopathogenesis of vulvovaginal candidiasis. Infect. Imm., 72, 2939-2946.

8. Ghannaoum, M.A. (2000) Potential role of phospholipases in virulence and fungal pathogenesis. Clin. Microbiol. Review, 13, 122143 . 
9. Kurtzman, C.P.; Fell, J.W. (1998). The Yeast. A taxonomic study. $4^{\text {nd }}$ edn. Elsevier, Amsterdam.

10. Larone, D.H. (1995). Medically important fungi. A guide to identification. AMS Press, Washington, DC.

11. Luo, G.; Samaranayake, L.P.; Yau, J.Y.Y. (2001). Candida species exhibit differential in vitro hemolytic activities. J. Clin. Microbiol., 39, 2971-2974.

12. Manns, J.M.; Mosser, D.M.; Buckley, H.R. (1994). Production of a hemolytic factor by Candida albicans. Infect. Imm., 62, 5154-5156.

13. Marrazo, J.M. (2003). Vulvovaginal candidiasis - over the counter doesn't seen to lead to resistance. B.M.J., 326, 993-994.

14. Otto, B.R.; VerweiJ-Van, A.M.J.J.; Maclar, D.M. (1992). Transferrins and heme compounds as iron sources pathogenic bacteria. Crit. Rev. Microbiol., 18, 217-233.

15. Price, M.F.; Wilkinson, I.D.; Gentry, L.O. (1982). Plate methods for detection of phosfolipases in Candida albicans. Sabour, 20, 15-20.

16. Rosa, M.I.; Rumel, D. (2004). Fatores associados à candidíase vulvovaginal: estudo exploratório. Rev. Bras. Ginecol. Obst., 26, 65-70.

17. Ruchel, R.; Tgegeler, R.; Trost, M. (1982). A comparison of secretory proteinase from differents strains of Candida albicans. Sabor, 20, 233-44.
18. Sobel, J.D.; CHAIM, W. (1996). Treatment of Torulopsis glabrata vaginitis: retrospective review of boric acid therapy. Clin. Infect. Dis., 24, 649-652.

19. Soll, D.R.; Galask, R.; Schmid, J.; Hanna, C.; Morrow, B. (1991). Genetic dissimilarity of commensal strains of Candida spp. Carried in different anatomical locations of the same healthy women. $J$. Clin. Microbiol., 29, 1702-1710.

20. Sugita, T.; Kurosaka, S.; Yajitate, M.; Sato, H.; Nishikawa, A. (2002). Extracellular proteinase and phospholipase activity of three genotypic strains of a human pathogenic yeast, Candida albicans. Microbiol. Imm., 46, 881-883.

21. Vidotto, V.; Koga-Ito, C.Y.; Milano, R.; Fianchino, B.; Potón, J. (1999). Correlation between germ tube production, phospholipase activity and serotype distribuition in Candida albicans. Rev. Iberoam. Micol., 16, 208-210.

22. Vilela, M.M.S.; Kamei, K.; Sano, A.; Tanaka, R.; Uno, J.; Takahashi, I.; Ito, J.; Yarita, K.; Miyji, M. (2002). Pathogenicity and virulence of Candida dubliniensis: comparison with C. albicans. Med. Mycol., 40, 249-257.

23. Ziarrusta, G.B. (2002). Vulvovaginitis candidiásica. Rev. Iberoam. Micol., 19, 22-24. 